\title{
Botryosphaeriaceae species overlap on four unrelated, native South African hosts
}

\author{
Fahimeh JAMI $^{2 *}$, Bernard SLIPPERS ${ }^{2}$, Michael J. WINGFIELD ${ }^{1}$, Marieka GRYZENHOUT ${ }^{3}$ \\ ${ }^{1}$ Department of Microbiology and Plant Pathology, Forestry and Agricultural Biotechnology Institute (FABI), \\ University of Pretoria, Pretoria 0002, South Africa \\ ${ }^{2}$ Department of Genetics, Forestry and Agricultural Biotechnology Institute (FABI), University of Pretoria, Pretoria \\ 0002, South Africa \\ ${ }^{3}$ Department of Plant Sciences, University of the Free State, Bloemfontein, South Africa, \\ * Corresponding author. Tel.: +27124205819; Fax:0027 124203960.E-mail address: Fahimeh.jami@fabi.up.ac.za
}

\section{ABSTRACT}

The Botryosphaeriaceae represents an important and diverse family of latent fungal pathogens of woody plants. While some species appear to have wide host ranges, others are reported only from single hosts. It is, however, not clear whether apparently narrow host ranges reflect specificity or if this is an artifact of sampling. We address this question by sampling leaves and branches of native South African trees from four different families, including Acacia karroo (Fabaceae), Celtis africana (Cannabaceae), Searsia lancea (Anacardiaceae) and Gymnosporia buxifolia (Celastraceae). As part of this process, two new species of the Botryosphaeriaceae, namely Tiarosporella africana sp. nov. and Aplosporella javeedii sp. nov., emerged from sequence comparisons based on the ITS rDNA, TEF- $1 \alpha, \beta$-tubulin and LSU rDNA gene regions. An additional five known species were identified including Neofusicoccum parvum, N. kwambonambiense, Spencermartinsia viticola, Diplodia pseudoseriata and Botryosphaeria dothidea. Despite extensive sampling of the trees, some of these species were not isolated on many of the hosts as was expected. For example, B. dothidea, which is known to have a broad host range but was found only on A. karroo. This could have resulted from the fact that it is a rare species in the region. With the exception of $S$. lancea, which was infected by $A$. javeedii all the hosts were infected by more than one Botryosphaeriaceae species. Collectively, the results suggest that some intrinsic host factors, possibly combined with local environmental conditions, affect the distribution and co-infectivity of various hosts by the Botryosphaeriaceae. 
This would counteract the general ability of a species in the Botryosphaeriaceae to infect a broad range of plants. The combination of host and environmental factors might also explain why some Botryosphaeriaceae with apparently broad host ranges, are found on different suites of hosts in different areas of the world.

Keywords Botryosphaeriales, host pattern, Tiarosporella, Aplosporella, Taxonomy

\section{Introduction}

Fungi residing in the Botryosphaeriaceae (Ascomycota: Botryosphaeriales) have been characterised from a wide variety of trees. They commonly occur as endophytes in asymptomatic plant tissues (Smith et al. 1996b), but some species are also important pathogens. The shift in habit from endophyte to being virulent pathogens typically occurs when trees are subjected to stress (Slippers and Wingfield 2007). Some Botryosphaeriaceae infect several different hosts, which may or may not be related to each other. Other species are known from only a single host. While there appear to be some distinct patters of host association for those species that infect conifers as opposed to angiosperms (De Wet et al. 2008), relatively little is known regarding the epidemiology and host ranges of these intriguing fungi.

Species of Botryosphaeriaceae occur widely in South Africa and they have been found on virtually every tree species that has been sampled for them. Hosts include native trees such as Terminalia catappa (Myrtales: Combretaceae) (Begoude et al. 2010), Pterocarpus angolensis (Fabales: Fabaceae) (Mehl et al. 2011), Syzygium cordatum (Myrtales: Myrtaceae) (Pavlic et al. 2007), Acacia melifera (Fabales: Fabaceae) (Slippers et al. 2013), A. karroo (Jami et al. 2012), and woody species of Leucadendron, Leucospermum and Protea (Proteales: Proteaceae) (Denman et al. 2003). Non-native hosts of the Botryosphaeriaceae in South Africa include Pinus spp. (Pinales: Pinaceae), Eucalyptus spp. (Myrtales: Myrtaceae), Prunus spp. (Rosales: Rosaceae), and Vitis vinifera (Vitales: Vitaceae) (Damm et al. 2007a; Smith et al. 1996a; Van Niekerk et al. 2004). Despite relatively intensive sampling over many years, most native woody plants in South Africa have not been sampled for the presence of Botryosphaeriaceae.

Some species of Botryosphaeriaceae have broad host ranges, occurring on both native and non-native hosts in a sampled area. For example, Neofusicoccum vitifusiforme (Van Niekerk \& Crous) Crous, Slippers \& A.J.L. Phillips, N. australe (Slippers, Crous \& M.J. Wingf.) Crous, 
Slippers \& A.J.L. Phillips, N. parvum (Pennycook \& Samuels) Crous, Slippers \& A.J.L. Phillips, N. luteum (Pennycook \& Samuels) Crous, Slippers \& A.J.L. Phillips, N. kwambonambiense Pavlic, Slippers \& M.J. Wingf., Lasiodiplodia theobromae (Pat.) Griffon \& Maubl., Diplodia seriata De Not., Spencermartinsia viticola (A.J.L. Phillips \& J. Luque) A.J.L. Phillips, A. Alves \& Crous and Botryosphaeria dothidea (Moug. ex Fr.) Ces. \& De Not., have been found on various native and non-native trees in South Africa (Damm et al. 2007a; Denman et al. 2003; Pavlic et al. 2007, 2009a; Pillay et al. 2013; Slippers et al. 2007; Smith et al. 1996a; Van Niekerk et al. 2004). Some Botryosphaeriaceae can also infect a variety of native hosts and examples include Dothiorella dulcispinae Jami, Gryzenh., Slippers \& M.J. Wingf., Phaeobotryosphaeria variabilis F.J.J. van der Walt, Slippers \& G.J. Marais, and Spencermartinsia rosulata F.J.J. van der Walt, Slippers \& G.J. Marais, that infect different Acacia species (Jami et al. 2012; Slippers et al. 2013), L. pseudotheobromae A.J.L. Phillips, A. Alves \& Crous from Pt. angolensis, T. catappa and S. cordatum (Begoude et al. 2010; Mehl et al. 2011; Pillay et al. 2013), and N. protearum (Denman \& Crous) Crous, Slippers \& A.J.L. Phillips that infects Leucadendron laureolum $\times$ Ldn. salignum and Protea spp. (Denman et al. 2003). In contrast, some species have thus far been found only on a single host plant, for example Tiarosporella urbis-rosarum Jami, Gryzenh., Slippers \& M.J. Wingf., Diplodia allocellula Jami, Gryzenh., Slippers \& M.J. Wingf., Dothiorella brevicollis Jami, Gryzenh., Slippers \& M.J. Wingf., Do. oblonga F.J.J. van der Walt, Slippers \& G.J. Marais, Spencermartinsia pretoriensis Jami, Gryzenh., Slippers \& M.J. Wingf., S. capri-amissi, N. viticlavatum (Van Niekerk \& Crous) Crous, Slippers \& A.J.L. Phillips and L. pyriformis F.J.J. van der Walt, Slippers \& G.J. Marais (Jami et al. 2013; Slippers et al. 2013; Van Niekerk et al. 2004). This pattern of association could be attributed to a sampling effect. For example, sampling has not been particularly intensive for most tree species and sampling has also tended to focus on particular areas. It is thus not clear whether species known from a limited number of hosts are host specific, or if they simply have not been sampled from other hosts.

Acacia karroo has been subjected to intensive surveys for Botryosphaeriaceae across various geographical areas in southern Africa (Jami et al. 2012, 2013; Slippers et al. 2013). A large diversity of Botryosphaeriaceae has been found during these studies, including T. urbisrosarum, D. allocellula, P. variabilis, Do. brevicollis, Do. dulcispinae, N. vitifusiforme, S. viticola, S. pretoriensis, S. rosulata, N. australe, N. parvum, N. kwambonambiense, B. dothidea and $L$. theobromae. Some of these species are known from hosts other than A. karroo, while 
others have been reported only from this tree. As in other systems, the question arises as to whether this reflects the level of host specificity or if it is due to a sampling bias.

The aim of this study was to determine patterns of overlap of the Botryosphaeriaceae occurring on A. karroo and three unrelated and commonly occurring tree species that grow in areas surrounding it. These trees included Celtis africana (Rosales: Cannabaceae), Searsia lancea (Sapindales: Anacardiaceae), and Gymnosporia buxifolia (Celastrales: Celastraceae). Sampling was made at a particular point in time and at a single location to exclude the effect of temporal and geographical diversity. We also considered the level of diversity of Botryosphaeriaceae in different tissues on these hosts. It was thus anticipated that the results would provide a rudimentary estimation of the patters of diversity for Botryosphaeriaceae in South Africa that might be expected across different hosts.

\section{Materials and methods}

\section{Collection of samples and isolations}

Healthy plant material from A. karroo and three commonly occurring and surrounding tree species, namely C. africana, S. lancea and G. buxifolia were collected in October 2011 (spring). Ten healthy and co-occurring trees of each species were randomly chosen for sampling. Three healthy branches including leaves were collected from each tree, placed in paper bags, and transferred to the laboratory to be processed for isolations. Samples were obtained from a nature reserve area in Pretoria, South Africa.

For each sample, 12 pieces $(0.5 \mathrm{~cm}$ in length) of tissue were taken from each branch and 12 pieces were cut from the simple leaves. The samples were surface disinfested in 10\% hydrogen peroxide for two minutes, rinsed three times in sterile distilled water and cultured on $2 \%$ malt extract agar (MEA) (Biolab, S.A.). Single hyphal-tips of isolates displaying a cultural morphology typical of the Botryosphaeriaceae, such as rapid growth and white to black mycelium with aerial hyphae, were transferred to fresh plates until pure cultures had been obtained. Single hyphal-tip cultures of these isolates are maintained in the Culture Collection (CMW) of the Forestry and Agricultural Biotechnology Institute (FABI), University of Pretoria, Pretoria, South Africa, and duplicate isolates of the new species were deposited in the collection of the Centraalbureau voor Schimmelcultures (CBS), The Netherlands. 


\section{DNA sequence analyses}

Isolates utilised in this study were grouped based on culture morphology. DNA was extracted (Lee and Taylor 1990) from fungal mycelium of 5-day-old single hyphal-tip cultures of three to five representatives for each morphological group. Four gene regions were used for comparison based phylogenetic analyses to determine the identities of the unknown isolates. These included the internal transcribed spacer region of the ribosomal RNA (rRNA) operon amplified with primers ITS-1F (Gardes and Bruns 1993) and ITS-4 (White et al. 1990), the translation elongation factor 1- $\alpha(\mathrm{EF} 1-\alpha)$ gene amplified with primers EF1-728F and EF1-986R (Carbone and Kohn 1999), the $\beta$-tubulin gene using primers Bt2a and Bt2b (Glass and Donaldson 1995) and the large subunit rDNA (LSU) gene region using primers LR0 and LR5 (Vilgalys and Hester 1990).

The conditions and procedures for PCR, sequencing and phylogenetic analyses were the same as those described in Jami et al. (2012). The phylogenetic analyses for all the datasets were performed using Maximum Likelihood (ML) and Bayesian analyses. For ML analyses, the best nucleotide substitution models for each dataset were found separately with Modeltest 3.7 (Posada and Buckley 2004). The model for $\mathrm{GTR}+\mathrm{G}(\mathrm{G}=0.2390, \mathrm{I}=0.0)$ was chosen for the combined datasets of ITS, LSU, TEF-1 $\alpha, \beta$-tubulin. The ML analyses were performed in PAUP $4.0 \mathrm{~b} 10$ and confidence levels were determined with 1000 bootstrap replications. Bayesian analyses using the Markov Chain Monte Carlo (MCMC) method were performed to ascertain the topology of trees obtained with ML. The MCMC analyses, with four chains, started from random tree topology and lasted 3,000,000 generations. Trees were saved every 100th generation. The burn-in number was graphically estimated (3000) from the likelihood scores and trees outside this point were discarded in the analyses. The consensus trees were constructed in MEGA version 4 and posterior probabilities were assigned to branches after a $60 \%$ majority rule.

\section{Morphological characteristics}

To induce sporulation, cultures were inoculated onto sterilized twigs of $A$. karroo placed on the surface of $2 \%$ MEA (Biolab), and these were incubated at $25{ }^{\circ} \mathrm{C}$ under near-UV light (Jami et al. 2012). Fifty released conidia, and 30 pycnidia and conidiogenous cells were 
measured for the isolates chosen to represent holotypes for each putative new species, and the ranges and averages were computed. Measurements and digital images were made with an HRc Axiocam digital camera and accompanying Axiovision 3.1 software (Carl Zeiss Ltd., Munich, Germany). Dried cultures representing type specimens were deposited in the National Collection of Fungi (PREM), Pretoria, South Africa.

Colony morphology and colour were determined for cultures grown on MEA at $5-35^{\circ} \mathrm{C}$, at $5^{\circ} \mathrm{C}$ intervals, in the dark. For these, $6 \mathrm{~mm}$ diam. mycelial plugs were taken from the edges of actively growing 4-day-old single conidial cultures, and transferred to the centres of $90 \mathrm{~mm}$ diam. Petri dishes containing MEA. Three replicate plates were used for each isolate per temperature. Two measurements perpendicular to each other were taken of the colony diameter daily until the mycelium of the fastest growing isolates had covered the plates and averages were computed. Colony colours were assigned using the designations of Rayner (1970).

\section{Statistical analyses of species diversity}

To determine the variability and overlap of the Botryosphaeriaceae species from the four hosts, data generated from the isolations were subjected to statistical analyses to determine whether the variation was significant or not. In addition, the variability and overlap in diversity and species between tissue types (branches and leaves) for each host and in total were determined. A one-way ANOVA with the general linear model procedure was used with JMP (version 10, SAS Institute Inc. 2012).

\section{Results}

\section{Collection of samples and isolates}

A total of 191 isolates were obtained from the four host trees, with 119 from branches and 72 from leaves. These included 82 isolates from $A$. karroo (50\% of sampled trees), 72 from C. africana ( $40 \%$ of sampled trees), three from S. lancea (10\% of sampled trees) and 34 isolates from G. buxifolia (50\% of sampled trees). Isolates from A. karroo included $42.9 \%$ of total isolates, while those from $S$. lancea included only $1.5 \%$ of the total collection. 


\section{DNA sequence analyses}

The sequence datasets for the ITS, TEF- $1 \alpha, \beta$-tubulin and LSU rDNA regions were analyzed individually and in combination. The ITS sequence dataset contained 552 characters (excluding 366 and including 186 characters) with $\mathrm{RI}=0.972, \mathrm{RC}=0.809, \mathrm{HI}=0.167$ and $\mathrm{TL}=$ 301.8. The TEF-1 $\alpha$ dataset contained 287 characters (excluding 60 and including 227 characters) with $\mathrm{RI}=0.891, \mathrm{RC}=0.550, \mathrm{HI}=0.383$ and $\mathrm{TL}=523$. The $\beta$-tubulin dataset contained 366 characters (excluding 239 and including 127 characters) with $\mathrm{RI}=0.965, \mathrm{RC}=0.825, \mathrm{HI}=$ 0.302 , and $\mathrm{TL}=185.1$. The LSU dataset contained 848 characters (excluding 460 and including 484 characters) with $\mathrm{RI}=0.983, \mathrm{RC}=0.906, \mathrm{HI}=0.078$ and $\mathrm{TL}=548.8$. The tree statistics for the combined dataset were $\mathrm{RI}=0.854, \mathrm{RC}=0.416, \mathrm{HI}=0.513, \mathrm{TL}=2148$ (TreeBase Accession No. S12358), and the partition homogeneity test (PHT) on the datasets gave a P-value of 0.01 .

The topology of the trees emerging from the ML, MP and MrBayes analyses were similar for the individual gene regions, as well as in the combined analyses, with regards to the clades representing species isolated in this study. Seven clades were identified in all the analyses and these represented S. viticola, B. dothidea, N. parvum, N. kwambonambiense, D. pseudoseriata and two unidentified groups within the clades accommodating Aplosporella and Tiarosporella, respectively (Fig. 1). The distinct groupings of two new species in Aplosporella and Tiarosporella were based on fixed sequence variants linked to the two groups and identified in the datasets (Tables $2 \& 3$ ).

From A. karroo, three species were identified, namely B. dothidea (CMW38114, CMW38115, CMW38116), D. pseudoseriata (CMW38137, CMW38138) and S. viticola (CMW38079). Four species, namely S. viticola (CMW38082), N. kwambonambiense (CMW38426), Tiarosporella sp. nov. (CMW38423, CMW38424, CMW38425, CMW38428) and Aplosporella sp. nov. (CMW38165, CMW38166, CMW38167) were isolated from C. africana. This is in contrast to $S$. viticola (CMW38080) and $N$. parvum (CMW38161) that were obtained from G. buxifolia. Only the Aplosporella sp. nov. (CMW38168 CMW38169, CMW38170) was identified from S. lancea. Spencermartinsia viticola was common among $A$. karroo, C. africana and G. buxifolia, but was not found on S. lancea. The Aplosporella sp. nov. overlapped on S. lancea and C. africana (Table 1, Fig. 6). 


\section{Morphological characteristics}

The isolates in the group corresponding to Tiarosporella in the DNA sequence comparisons were fast-growing with white, raised aerial mycelium around the edges of the culture, with gray centres viewed from the top and bottom of the plate. These cultures produced large hyaline conidia with appendages of different sizes. Isolates in the other six groups had dark gray or olivaceous colonies with aerial hyphae and dematiaceous conidia. Aplosporella isolates were slow growing, and had gray-olivaceous mycelium with light, irregular edges and mostly aseptate conidia that were narrow at the centres. Other known Aplosporella spp. have ellipsoidal to sub-cylindrical conidia. The substantial overlap in these morphological characters allowed only limited comparisons with characteristics published for the species.

\section{Statistical analyses of species diversity}

There were no statistically significant differences between species composition (not considering frequency of individual species) on the different hosts $(\mathrm{P}>0.05)$. Among the fungal species, S. viticola was the only one that had a host association that was significantly different from the other species $(\mathrm{P}<0.05)$ in terms of frequency of occurrence. It was dominant on three of the hosts with $79.3 \%$ of isolates from A. karroo, $55.6 \%$ of isolates from C. africana, and $88.2 \%$ of the isolates from G. buxifolia. There was no significant difference between the diversity of species found from leaves and branches $(\mathrm{P}>0.05)$. There was also no significant difference between the frequency of species found on leaves and branches $(\mathrm{P}>0.05)$ (Fig. 4). Of the seven isolated species, S. viticola was the most commonly isolated from both leaves and branches. N. parvum, N. kwambonambiense, Aplosporella sp. nov. and Tiarosporella sp. nov. were found only on branches, while D. pseudoseriata and B. dothidea were exclusively isolated from leaves (Fig. 5).

\section{Taxonomy}

The phylogenetic analyses revealed two new taxa and these taxa were supported by morphological studies. These species are described below. 
Aplosporella javeedii Jami, Gryzenh., Slippers \& M.J. Wingf. sp. nov.

(Fig 2)

MycoBank No.: MB803637

Etymology: The name is derived from the Persian name "Javeed Jami", meaning "long lived". No teleomorph observed.

Pycnidia formed on MEA in 2 weeks, solitary, globose, grey-olivaceous (23‥'i), unilocular, immersed to semi-immersed, average $850 \times 820 \mu \mathrm{m}$, wall 6-10 cell layers thick, outer layers composed of dark-brown textura angularis, becoming thin-walled and hyaline towards the inner region. Conidiogenous cells formed from the cells lining the inner walls of the pycnidia, holoblastic, determinate, simple, ellipsoidal and slightly tapered towards the apex, hyaline. Conidia aseptate, initially hyaline, becoming dark brown, smooth-walled, broadly ellipsoidal to sub-cylindrical, with rounded ends, (18.3-)21.2-24.6(-26.7) × (6.9-)8.1-9.6(-10.1) $\mu \mathrm{m}$.

Culture characteristics: On MEA after 5 days in the dark, olivaceous to grey-olivaceous $\left(23^{\cdots \cdots} \mathrm{i}\right)$, similar in reverse; aerial mycelium appressed, floccose, white to smoke-grey. Colonies flat with undulate edge. Growth at $5-35^{\circ} \mathrm{C}$. Growth rate $10 \mathrm{~mm}$ per day at an optimal temperature of $25^{\circ} \mathrm{C}$; covering the agar surface in a $90 \mathrm{~mm}$ diam. Petri dish after 9 days in the dark.

Specimens examined: South Africa, Gauteng Province, Pretoria, November 2011, F. Jami \& M. Gryzenhout, from healthy wood section of Celtis africana, holotype PREM60865, ex-type culture CMW38165 = CBS133954.

Additional specimens: South Africa, Gauteng Province, Pretoria, November 2011, F. Jami \& M. Gryzenhout, from healthy branch of Celtis africana, paratype (living cultures CMW38166, CMW38167 $=$ CBS135852 $=$ PREM60880) and Searsia lancea, paratype (living cultures CMW38168 = CBS135853 = PREM60881, CMW38169, CMW38170).

Tiarosporella africana Jami, Gryzenh., Slippers \& M.J. Wingf. sp. nov.

(Fig 3)

MycoBank No.: MB803638

Etymology: The name refers to the Africa and the continent from which this species was collected.

No teleomorph observed. 
Pycnidia formed on Acacia karroo twigs on MEA in 2-3 weeks under ultra-violet (UV), solitary, globose, dark black $\left(29^{\cdots \cdots} \mathrm{m}\right)$, unilocular, immersed, average $1100 \times 300 \mu \mathrm{m}$, wall 5-7 cell layers thick, outer layers composed of dark-brown textura angularis, becoming thin-walled and hyaline towards the inner region.

Conidiogenous cells formed from the cells lining the inner walls of the pycnidia, holoblastic, determinate, simple, ellipsoidal and slightly tapered towards the apex, hyaline. Conidia aerogenous, solitary, hyaline, smooth, thin-walled, straight, fusiform with truncate base and obtuse apex, (15.6-)19.5-31.8(-35.5) × (7.4-)8.6-11.6(-12.2) $\mu \mathrm{m}$. During development, conidia are in a gelatinous sheath which may remain as an apical, hyaline, cone-like appendage that are $(23.8-) 24.5-45.4(-49.9) \times(11.5-) 12.8-22.2(-25.11) \mu \mathrm{m}$.

Culture characteristics: on MEA with appressed mycelial mats, pycnidia emerging after 2-3 weeks under near-ultraviolet light on A. karroo twigs. Mycelium gray, becoming dark gray from the center, white and fluffy at the edges, reverse dark gray to black. Growth at $5-35^{\circ} \mathrm{C}$. Growth rate $22.5 \mathrm{~mm}$ per day at an optimal temperature of $30^{\circ} \mathrm{C}$; covering the agar surface in a $90 \mathrm{~mm}$ diam. Petri dish after 4 days in the dark.

Specimens examined: South Africa, Gauteng Province, Pretoria, November 2011, F. Jami \& M. Gryzenhout, from healthy wood section of Celtis africana, holotype PREM60866 resulting from inoculations of living isolate to A. karroo twigs, living ex-type cultures CMW38423 = CBS 133854.

Additional specimens: South Africa, Gauteng Province, Pretoria, November 2011, F. Jami \& M. Gryzenhout, from healthy branch of Celtis africana, paratype (living cultures CMW38424 = CBS135850 = PREM60882, CMW38425 = CBS135851 = PREM60882, CMW38428).

\section{Discussion}

Seven Botryosphaeriaceae species were identified from the four tree species growing in close proximity to each other. These fungi included species known in South Africa (N. parvum, N. kwambonambiense, S. viticola, D. pseudoseriata, B. dothidea) and the two new taxa Tiarosporella africana and Aplosporella javeedii. Five of these species occurred on only a single host, but A. javeedii was found on two and S. viticola occurred on three of the tree species 
sampled. Results of this study, based on the single location with only four hosts sampled, represent high levels of biodiversity for the Botryosphaeriaceae.

Botryosphaeria dothidea, N. parvum, N. kwambonambiense, T. africana and D. pseudoseriata were found only on one host in this study. This could be interpreted as host specificity, as has been postulated for other endophytes (Cohen 2004, 2006; Porras-Alfaro and Bayman 2011; Zhou and Hyde 2001). Some Botryosphaeriaceae species are also thought to have some level of host preference, such as D. pinea, D. scrobiculata and D. cupressi that are found predominantly on certain conifers (Alves et al. 2006; De Wet et al. 2008). However, we do not expect that this pattern reflects host specificity in these cases, because all the fungi are known from previous studies to have broad host ranges. In particular, B. dothidea, L. theobromae and N. parvum are known to have extremely broad host ranges (Punithalingam 1976; Sakalidis et al. 2013; Slippers and Wingfield 2007). In South Africa, B. dothidea, has been reported previously from Acacia spp., Eucalyptus spp., Podocarpus spp., Syzygium spp. and Heteropyxis natalensis (Pavlic et al. 2007; Slippers et al. 2013; Smith et al. 2001). Likewise, N. parvum has been found on S. cordatum, Eucalyptus spp., and T. catappa (Begoude et al. 2010; Pavlic et al. 2007; Slippers et al. 2004). Also, L. theobromae has been identified from V. vinifera, S. cordatum, T. catappa and Pt. angolensis in South Africa (Begoude et al. 2010; Mehl et al. 2011; Pavlic et al. 2007; Van Niekerk et al. 2004). Given that sampling was relatively intensive at this single location, the data suggest that the occurrence of species in this study might reflect factors influencing distribution other than host specificity, such as environmental factors, and sampling effect. To determine true host ranges of these fungi, considerably more intensive and wider sampling will need to be done.

Host specificity has not previously been found for the Botryosphaeriaceae and this was also true for the present study. In this study, S. viticola was isolated from three different families of trees Fabaceae, Cannabaceae and Celastraceae but not from the Anacardiaceae. Although some previous studies have considered larger numbers of potential host plants and were conducted over larger areas (Sakalidis et al. 2011a; Taylor et al. 2009), patterns of host association were not clear. For example, Sakalidis et al. (2011a) showed that at one site, Pseudofusicoccum kimberleyense overlapped on hosts residing in three families (Fabaceae, Myrtaceae and Moraceae), but similar levels of overlap were not observed at other sites. Taylor et al. (2009) showed similar results with Aplosporella yalgorensis that were found on two tree 
species E. gomphocephala (Myrtaceae) and Acacia cochlearis (Fabaceae) at one site but it was not found on these trees at another sampling location. Apart from two species, Do. moneti and Do. santali, that were restricted to A. rostellifera and Santalum acuminatum (Santalaceae) respectively, the remaining species did not show any pattern of host association (Taylor et al. 2009). Several factors could affect these patterns of endophyte infection on a particular plant host, including biotic (e.g. plant defences, competition, etc.) and abiotic factors (e.g. local climate affecting growth, sporulation, etc.). None of these factors have, however, been studied in detail for the Botryosphaeriaceae on tree hosts.

The number of Botryosphaeriaceae species infecting the different tree hosts varied considerably in this study. Most of the trees sampled were infected by multiple (up to four) species of Botryosphaeriaceae. For example, C. africana had the most diverse assemblage of these fungi while $S$. lancea had the lowest level of diversity. These results are similar to the study of Sakalidis et al. (2011a) where 11 Botryosphaeriaceae species were found on both Adansonia gregorii and native surrounding trees at three sites in Australia. In that study, each host showed a different Botryosphaeriaceae species diversity. For example, A. gregorii showed the greatest species diversity (Lang et al. 2011) while Melaleuca sp. and Calytrix sp. were infected only by one species. Furthermore, the overlapping seven species was inconsistently found on hosts at the various sites (Sakalidis et al. 2011a). Taylor et al. (2009) showed similar results where some native Australian trees were hosts to numerous Botryosphaeriaceae while other native trees were host to only a single species.

In terms of understanding host defences, S. lancea could offer an interesting opportunity for further studies. The abundance of Botryosphaeriaceae found on the other hosts compared to this host (only $1.5 \%$ of the total number of isolates) might suggest some characteristic of $S$. lancea that makes it less favourable for infection by these fungi. Future studies should consider the Botryosphaeriaceae on this tree in other areas of South Africa and also biochemical characteristics of this tree that might explain the low number of Botryosphaeriaceae in this tree as compared to, for instance, A. karroo.

This study revealed a number of new hosts for some of the Botryosphaeriaceae. For example, we isolated S. viticola on two new native hosts, namely C. africana and G. buxifolia. This fungus was previously known from Prunus spp., V. vinifera, A. karroo and A. mellifera in South Africa (Damm et al. 2007a; Jami et al. 2013; Slippers et al. 2013; Van Niekerk et al. 
2004). Spencermartinsia viticola was originally found on grapevine in Spain (Luque et al. 2005), but has since been reported from other areas on this host (Úrbez-Torres et al. 2007) and from the other hosts such as Populus cathayana (Zhang et al. 2009), and citrus (Adesemoye and Eskalen 2011). There is a clear association of this fungus with $V$. vinifera although this is clearly not fixed. The question thus arises as to where the fungus might be native and whether it has moved from commercially propagated to native plants or vice versa.

Neofusicoccum kwambonambiense represents another example of a species in the Botryosphaeriaceae that was isolated from C. africana for the first time in this study. This fungus was previously reported from Syzygium cordatum, Eucalyptus grandis and A. karroo in South Africa (Pavlic et al. 2009a; Pillay et al. 2013), from E. dunnii and Corymbia torelliana in Australia (Sakalidis et al. 2011b), and also from V. vinifera in Uruguay (Abreo et al. 2013). Such expansion of the known host range following expanded sampling appears to be a common pattern of recent studies on the Botryosphaeriaceae, and these are changing perceptions of host association drastically. For example, $N$. eucalyptorum was initially thought to be specific to Eucalyptus spp. in South Africa and Australia (Slippers et al., 2004), but was later found on other hosts in Uruguay (Pérez et al. 2009). These findings suggest that very extensive and global sampling will be necessary to fully understand the host associations and distribution of the Botryosphaeriaceae. For the present, caution would be advisable when drawing conclusions regarding host association and distribution of these fungi.

Some endophytes are known to be tissue specific (de Abreu et al. 2010; Fisher et al. 1993; Ganley and Newcombe 2006). However, results of this study provided no evidence that the Botryosphaeriaceae sampled are specific to either leaves or woody tissue, although the frequency of occurrence of some species such as S. viticola varied on tissue types. In the present study, N. kwambonambiense was found only on branch tissue of C. africana, and it has been isolated on branches of the other trees, including S. cordatum, E. dunnii and Corymbia torelliana (Pavlic et al. 2009b; Sakalidis et al. 2011b). In those studies, the samples were taken only from branches. Therefore, we cannot say that $N$. kwambonambiense is exclusive to branches. Similar to our study, Wunderlich et al. (2011) found no indication of tissue specificity for Botryosphaeriaceae species on $V$. vinifera. To fully explore the issue of variation in relative infection frequency of different species in different tissues, a metagenetics approach using either 
multi-species primers for the specific detection of Botryosphaeriaceous species (Ridgway et al. 2011) or next generation sequencing might be needed to overcome potential sampling bias.

A new species of Tiarosporella was described in this study from a native South African tree. Several Tiarosporella spp. have been reported from different hosts in the U.K, U.S.A, India, Yugoslavia and South Africa (Karadzic 2003; Sutton and Marasas 1976), but those were identified based only on morphology. Sequence data of only four species, namely T. tritici, T. graminis var. karroo, T. madreeya (Crous et al. 2006) and T. urbis-rosarum (Jami et al. 2012) are available in GenBank, all of which have been isolated from different hosts in South Africa (from Poaceae, Zygophyllaceae, Asteraceae and Fabaceae) (Jami et al. 2012; Sutton and Marasas 1976). It is not clear whether this current restriction of sequences for the genus exclusively from southern African isolates is due to a lack of sampling in some other regions of the world. While some areas have been fairly well sampled, this group could also have been overlooked during isolation work, because of its atypical culture morphology for Botryosphaeriaceae. For example, hyphae of Tiarosporella typically grow faster than the other Botryosphaeriaceae, but take longer to become grey after isolation. These atypical morphological characteristics and the fact that DNA sequence comparisons have not been conducted for species recorded outside South Africa might suggest problems regarding the identification of some collections of these fungi.

Recent studies have identified a number of unique Aplosporella spp. from different hosts and areas in South Africa. Of the four recently identified Aplosporella species, only $A$. yalgorensis was identified outside Africa from Acacia cochlearis and E. gomphocephala in Australia (Taylor et al. 2009). The other three species have all been described from southern Africa, with A. prunicola identified from Prunus in South Africa (Damm et al. 2007b), A. africana from A. mellifera in Namibia and A. papillata from A. tortillas and A. erioloba in South Africa (Slippers et al. 2013). The present study adds a fourth species, A. javeedii, and two new host records namely C. africana and S. lancea. Given fairly extensive sampling in other regions of the world, it would appear that southern Africa represents a centre of diversity for this group in the Botryosphaeriaceae.

The results of this study revealed the diversity of Botryosphaeriaceae on three previously unsampled plant families. They confirm the view that these fungi occur on most, if not all, woody plants. The data emerging from this and previous studies also suggest that many of these Botryosphaeriaceae are not host specific over the range of their distribution. Yet, the discovery 
of two new Botryosphaeriaceae species from a region that was previously intensively sampled for other hosts, suggest that host diversity does contribute to the diversity of Botryosphaeriaceae in an area. Thus, despite not being host specific, their host ranges might be limited to or more common on a certain suite of hosts in a particular area. The data, in particular from S. lancea, suggest that host factors could play a role in determining the diversity of Botryosphaeriaceae infection, even in the presence of species that have a general ability to infect many different hosts. Unravelling the limits of the host ranges of these different species, most representing plant pathogens, and how local environments influence them, remains one of the intriguing questions for this group of fungi.

\section{Acknowledgments}

We thank Mr. Jean Gryzenhout for assistance in collecting the samples and Dr. Seonju Marincowitz for providing advice regarding microscopy. Members of the Tree Protection Cooperative Programme (TPCP), the DST/NRF Centre of Excellence in Tree Health Biotechnology (CTHB) and the University of Pretoria, South Africa, are acknowledged for financial support.

\section{References}

Abreo E, Martinez S, Bettucci L, Lupo S, 2013. Characterization of Botryosphaeriaceae species associated with grapevines in Uruguay. Australasian Plant Pathology 42: 241-249.

Adesemoye AO, Eskalen A, 2011. First report of Spencermartinsia viticola, Neofusicoccum australe, and N. parvum causing branch canker of citrus in California. Plant Disease 95: 770.

Alves A, Correia A, Phillips AJL, 2006. Multi-gene genealogies and morphological data support Diplodia cupressi sp. nov., previously recognized as D. pinea f. sp. cupressi, as a distinct species. Fungal Diversity 23: 1-15.

Begoude BAD, Slippers B, Wingfield MJ, Roux J, 2010. Botryosphaeriaceae associated with Terminalia catappa in Cameroon, South Africa and Madagascar. Mycological Progress 9: 101123. 
Carbone I, Kohn LM, 1999. A method for designing primer sets for speciation studies in filamentous ascomycetes. Mycologia 91: 553-556.

Cohen SD, 2004. Endophytic-host selectivity of Discula umbrinella on Quercus alba and Quercus rubra characterized by infection, pathogenicity and mycelial compatibility. European Journal of Plant Pathology 110: 713-721.

Cohen SD, 2006. Host selectivity and genetic variation of Discula umbrinella isolates from two oak species: Analyses of intergenic spacer region sequences of ribosomal DNA. Microbial ecology 52: 463-469.

Crous PW, Slippers B, Wingfield MJ, Rheeder J, Marasas WFO, Philips AJL, Alves A, Burgess TI, Barber P, Groenewald JZ, 2006. Phylogenetic lineages in the Botryosphaeriaceae. Studies in Mycology 55: 235-253.

Damm U, Crous PW, Fourie PH, 2007a. Botryosphaeriaceae as potential pathogens of Prunus species in South Africa, with descriptions of Diplodia africana and Lasiodiplodia plurivora sp. nov. Mycologia 99: 664-680.

Damm U, Fourie PH, Crous PW., 2007b. Aplosporella prunicola, a novel species of anamorphic Botryosphaeriaceae. Fungal Diversity 27: 35-43.

de Abreu LM, Almeida AR, Salgado M, Pfenning LH, 2010. Fungal endophytes associated with the mistletoe Phoradendron perrottettii and its host tree Tapirira guianensis. Mycological Progress 9: 559-566.

De Wet J, Slippers B, Preisig O, Wingfield BD, Wingfield MJ, 2008. Phylogeny of the Botryosphaeriaceae reveals patterns of host association. Molecular Phylogenetics and Evolution 46: $116-126$.

Denman S, Crous PW, Groenewald JZ, Slippers B, Wingfield BD, Wingfield MJ, 2003. Circumscription of Botryosphaeria species associated with Proteaceae based on morphology and DNA sequence data. Mycologia 95: 294-307. 
Fisher P, Petrini O, Sutton B, 1993. A comparative study of fungal endophytes in leaves, xylem and bark of Eucalyptus in Australia and England. Sydowia 45: 338-345.

Ganley RJ, Newcombe G, 2006. Fungal endophytes in seeds and needles of Pinus monticola Mycological Research 110: 318-327.

Gardes M, Bruns TD, 1993. ITS primers with enhanced specificity for basidiomycetes-application to the identification of mycorrhizae and rusts. Molecular ecology 2: $113-118$.

Glass NL, Donaldson GC, 1995. Development of primer sets designed for use with the PCR to amplify conserved genes from filamentous ascomycetes. Applied and Environmental Microbiology 61: 1323-1330.

Jami F, Slippers B, Wingfield MJ, Gryzenhout M, 2012. Five new species of the Botryosphaeriaceae from Acacia karroo in South Africa. Cryptogamie Mycologie 33: 245-266.

Jami F, Slippers B, Wingfield MJ, Gryzenhout M, 2013. Greater Botryosphaeriaceae diversity in healthy than associated diseased Acacia karroo tree tissues. Australasian Plant Pathology 42: 421-430.

Karadzic D, 2003. Tiarosporella durmitorensis Karadzhic: distribution, description, epidemiology and impact in Yugoslavia. Proceedings of an international scientific conference marking 75 years of the Forest Research Institute of the Bulgarian Academy of Sciences, Sofia, Bulgaria 2: 183-186.

Lang C, Seven J, Polle A, 2011. Host preferences and differential contributions of deciduous tree species shape mycorrhizal species richness in a mixed Central European forest. Mycorrhiza 21: 297-308.

Lee SB, Taylor JW, 1990. Isolation of DNA from fungal mycelia and single spores In M. A. Innis, D. H. Gelfand, J. J. Sninsky, and T. J. White (ed.), PCR protocols. A guide to methods and applications Academic Press, San Diego, Calif 282-287. 
Luque J, Martos S, Phillips AJL, 2005. Botryosphaeria viticola sp. nov. on grapevines: a new species with a Dothiorella anamorph. Mycologia 97: 1111-1121.

Mehl JWM, Slippers B, Roux J, Wingfield MJ, 2011. Botryosphaeriaceae associated with Pterocarpus angolensis (kiaat) in South Africa. Mycologia 103: 534-553.

Pavlic D, Slippers B, Coutinho TA, Wingfield MJ, 2007. Botryosphaeriaceae occurring on native Syzygium cordatum in South Africa and their potential threat to Eucalyptus. Plant Pathology 56: 624-636.

Pavlic D, Slippers B, Coutinho TA, Wingfield MJ, 2009a. Molecular and phenotypic characterization of three phylogenetic species discovered within the Neofusicoccum parvum/N. ribis complex. Mycologia 101: 636-647.

Pavlic D, Slippers B, Coutinho TA, Wingfield MJ, 2009b. Multiple gene genealogies and phenotypic data reveal cryptic species of the Botryosphaeriaceae: A case study on the Neofusicoccum parvum/N. ribis complex. Molecular Phylogenetics and Evolution 51: 259-268.

Pérez CA, Wingfield MJ, Slippers B, Altier NA, Blanchette RA, 2009. Neofusicoccum eucalyptorum, a Eucalyptus pathogen, on native Myrtaceae in Uruguay. Plant Pathology 58: 964-970.

Piano E, Bertoli F, Romani M, Tava A, Riccioni L, Valvassori M, Carroni A, Pecetti L, 2005. Specificity of host-endophyte association in tall fescue populations from Sardinia, Italy. Crop Science 45: 1456-1463.

Pillay K, Slippers B, Wingfield MJ, Gryzenhout M, 2013. Diversity and distribution of coinfecting Botryosphaeriaceae from Eucalyptus grandis and Syzygium cordatum in South Africa. South African Journal of Botany 84: 38-43.

Porras-Alfaro A, Bayman P, 2011. Hidden fungi, emergent properties: endophytes and microbiomes. Annual Review of Phytopathology 49: 291-315. 
Posada D, Buckley TR, 2004. Model selection and model averaging in phylogenetics: advantages of Akaike information criterion and Bayesian approaches over likelihood ratio tests. Systematic Biology 53: 793-808.

Punithalingam E, 1976. Botryodiplodia theobromae. Commonwealth Mycological Institute, Kew, Surrey, England. 519.

Rayner RW, 1970. A mycological colour chart. Commonwealth Mycological Institute and British Mycological Society, Kew, Surrey, U. K.

Ridgway H, Amponsah N, Brown D, Baskarathevan J, Jones E, Jaspers M, 2011. Detection of botryosphaeriaceous species in environmental samples using a multi species primer pair. Plant Pathology 60: 1118-1127.

Sakalidis ML, Hardy GESJ, Burgess TI, 2011a. Endophytes as potential pathogens of the baobab species Adansonia gregorii: a focus on the Botryosphaeriaceae. Fungal Ecology 4: 1-14.

Sakalidis ML, Hardy GESJ, Burgess TI, 2011b. Use of the Genealogical Sorting Index (GSI) to delineate species boundaries in the Neofusicoccum parvum/Neofusicoccum ribis species complex. Molecular Phylogenetics and Evolution 60: 333-344.

Sakalidis ML, Slippers B, Wingfield BD, Hardy GESJ, Burgess TI, 2013. The challenge of understanding the origin, pathways and extent of fungal invasions: global populations of the Neofusicoccum parvum-N. ribis species complex. Diversity and Distributions 19: 873-1094.

Slippers B, Fourie G, Crous PW, Coutinho TA, Wingfield BD, Carnegie AJ, Wingfield MJ, 2004. Speciation and distribution of Botryosphaeria spp. on native and introduced Eucalyptus trees in Australia and South Africa. Studies in Mycology 50: 343-358.

Slippers B, Roux J, Wingfield MJ, Van der Walt FJJ, Jami F, Marais GJ, 2013. Confronting the constraints of morphological taxonomy in the fungi: A Botryosphaeriaceae case study. Persoonia (submitted). 
Slippers B, Smit WA, Crous PW, Coutinho TA, Wingfield BD, Wingfield MJ, 2007. Taxonomy, phylogeny and identification of Botryosphaeriaceae associated with pome and stone fruit trees in South Africa and other regions of the world. Plant Pathology 56: 128 -139.

Slippers B, Wingfield MJ, 2007. Botryosphaeriaceae as endophytes and latent pathogens of woody plants: diversity, ecology and impact. Fungal Biology Reviews 21: 90-106.

Smith H, Crous PW, Wingfield MJ, Coutinho TA, Wingfield BD, 2001. Botryosphaeria eucalyptorum sp. nov., a New Species in the B. dothidea Complex on Eucalyptus in South Africa. Mycologia 93: 277-285.

Smith H, Wingfield MJ, Petrini O, 1996a. Botryosphaeria dothidea endophytic in Eucalyptus grandis and Eucalyptus nitens in South Africa. Forest Ecology and Management 89: 189-195.

Smith H, Wingield MJ, Crous PW, Coutinho TA, 1996b. Sphaeropsis sapinea and Botryosphaeria dothidea endophytic in Pinus spp. and Eucalyptus spp. in South Africa. South African Journal of Botany 62: 86-88.

Sutton BC, Marasas WFO, 1976. Observations on Neottiosporina and Tiarosporella. Transactions of the British Mycological Society 67: 69-76.

Taylor K, Barber PA, Hardy GESJ, Burgess TI, 2009. Botryosphaeriaceae from tuart (Eucalyptus gomphocephala) woodland, including descriptions of four new species. Mycological Research 113: 337-353.

Úrbez-Torres J, Gubler W, Luque J, 2007. First report of Botryosphaeria iberica and B. viticola associated with grapevine decline in California. Plant Disease 91: 772-772.

Van Niekerk JM, Crous PW, Groenewald JZ, Fourie PH, Halleen F, 2004. DNA phylogeny, morphology and pathogenicity of Botryosphaeria species on grapevines. Mycologia 96: 781-798.

Vilgalys R, Hester M, 1990. Rapid genetic identification and mapping of enzymatically amplified ribosomal DNA from several Cryptococcus species. Journal of Bacteriology 172: 4238-4246. 
White TJ, Bruns T, Lee S, Taylor J, 1990. Amplification and direct sequencing of fungal ribosomal RNA genes for phylogenetics. PCR protocols: a guide to methods and applications. Eds., MA Innis, DH Gelfand, JJ Sninsky, and TJ White. Academic Press, New York 315-322.

Wunderlich N, Ash G, Steel C, Raman H, Cowling A, Savocchia S, 2011. Refining the biological factors affecting virulence of Botryosphaeriaceae on grapevines. Annals of Applied Biology 159: 467-477.

Zhang R, Guo X, Sun G, Tang M, Gleason ML, 2009. Dothiorella viticola on Populus cathayana in China: a new record. Mycotaxon 109: 129-135.

Zhou D, Hyde KD, 2001. Host-specificity, host-exclusivity, and host-recurrence in saprobic fungi. Mycological Research 105: 1449-1457. 


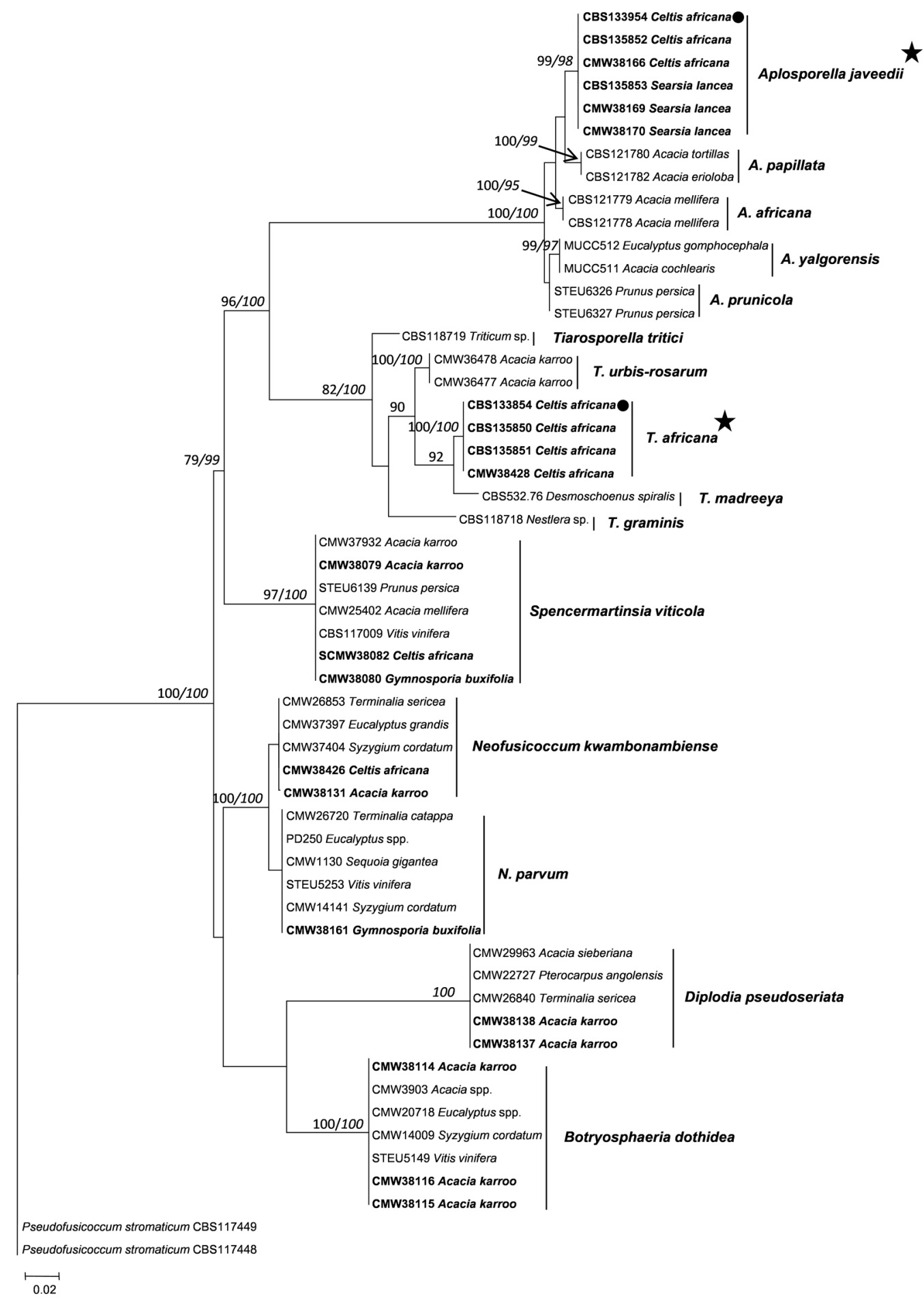

Fig. 1. Maximum Likelihood (ML) tree of the combined data set of ITS ribosomal DNA, TEF- $1 \alpha$, $\beta$-tubulin and LSU gene region sequences. Bootstrap values for ML (Piano et al. 2005) and MrBaysen (italic) above $60 \%$ are given at the nodes. The tree was rooted to Pseudofusicoccum stromaticum (CBS117448 and CBS117449). Isolates of this study are indicated as bold.

* Newly described species in this study. • indicates for ex-type isolates. 

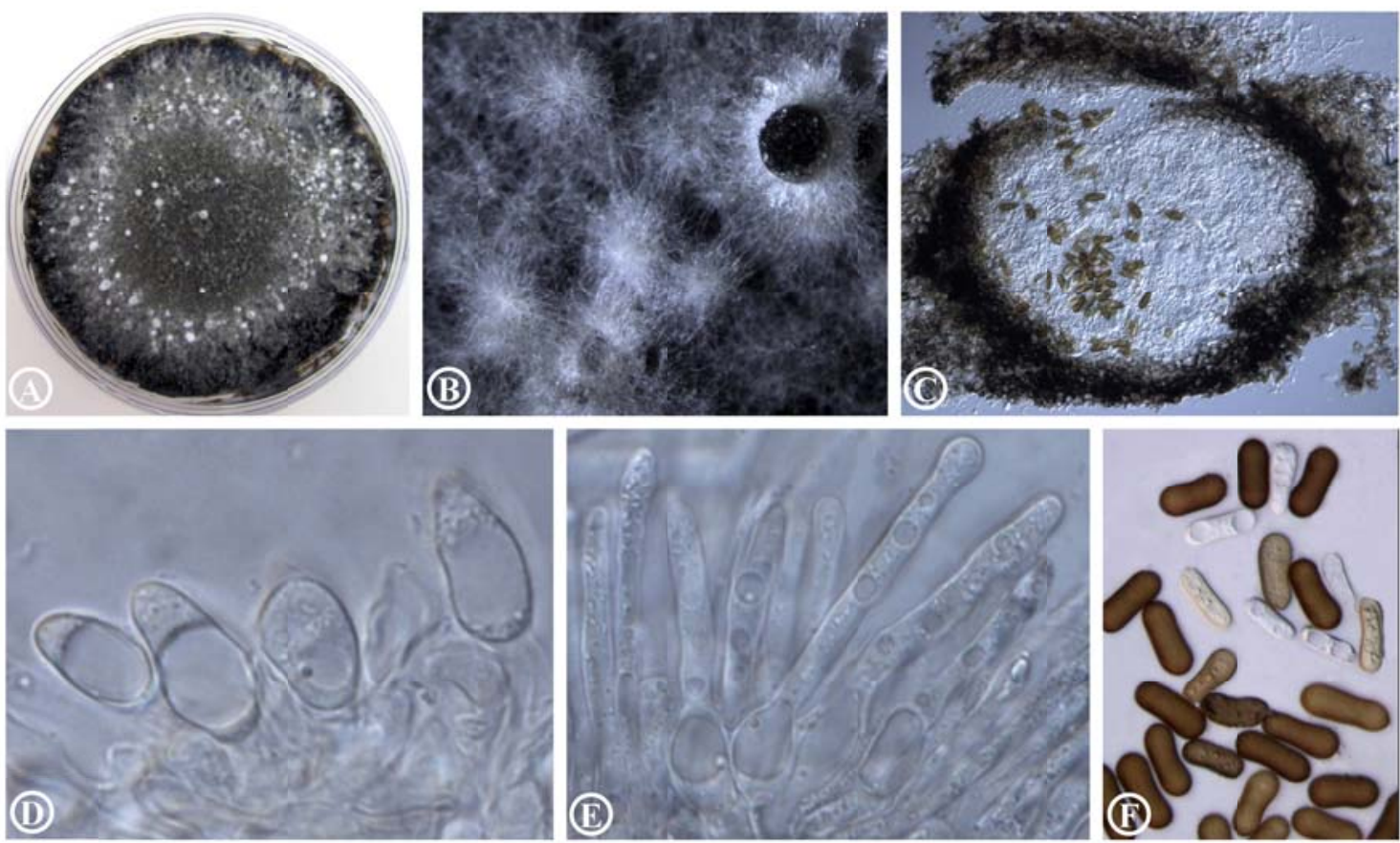

Fig 2. Micrographs of Aplosporella javeedii (A) Culture morphology on MEA in $25^{\circ} \mathrm{C}$. (B) Pycnidia (scale bar $=1000 \mu \mathrm{m}$ ). (C). Longitudinal section through pycnidium (scale bar $=100 \mu \mathrm{m}$ ). (D) Conidiogenous cells (scale bar $=5 \mu \mathrm{m})$. (E) Paraphyses $($ scale bar $=10 \mu \mathrm{m}) .(\mathbf{F})$ Conidia $($ scale bar $=5 \mu \mathrm{m})$ 

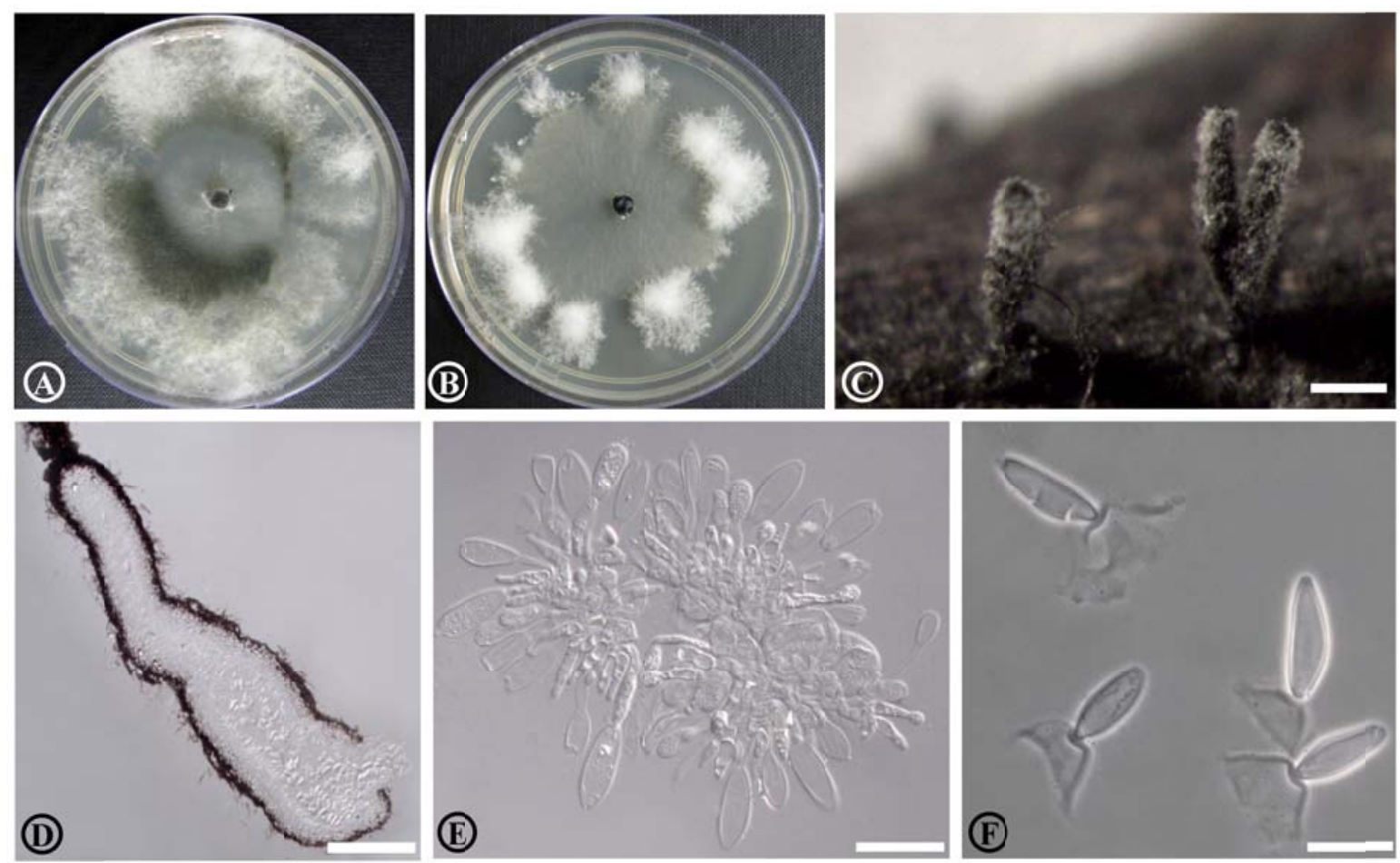

Fig 3. Micrographs of Tiarosporella africana. (A) Four days culture morphology on MEA in $30^{\circ} \mathrm{C}$. (B) Four days culture morphology on MEA in $25^{\circ} \mathrm{C}$. (C) Pycnidia (scale bar $=500 \mu \mathrm{m}$ ). (D) Longitudinal section through pycnidium (scale bar $=500 \mu \mathrm{m}) .(\mathbf{E})$ Conidiogenous cells and young conidia $($ scale bar $=20 \mu \mathrm{m}) .(\mathbf{F})$ Conidia $($ scale bar $=20 \mu \mathrm{m})$ 


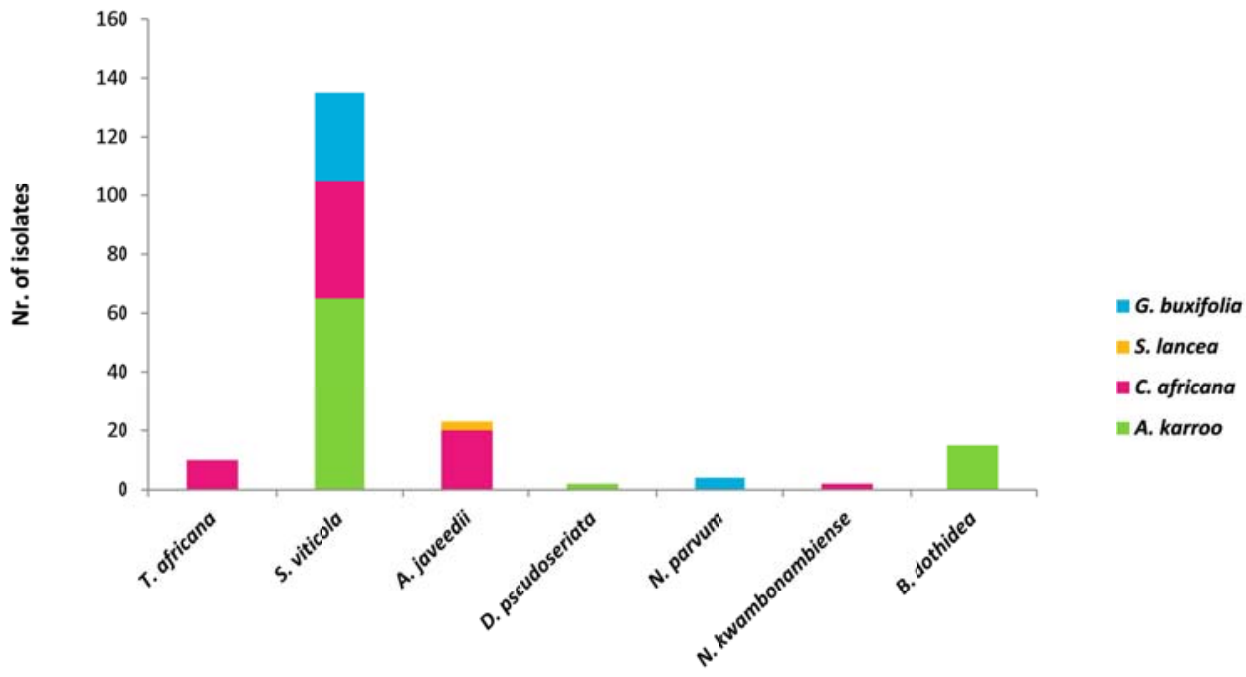

Fig. 4. Diversity of Botryosphaeriaceae species on four hosts, namely Acacia karroo, Celtis africana, Searsia lancea and Gymnosporia buxifolia 


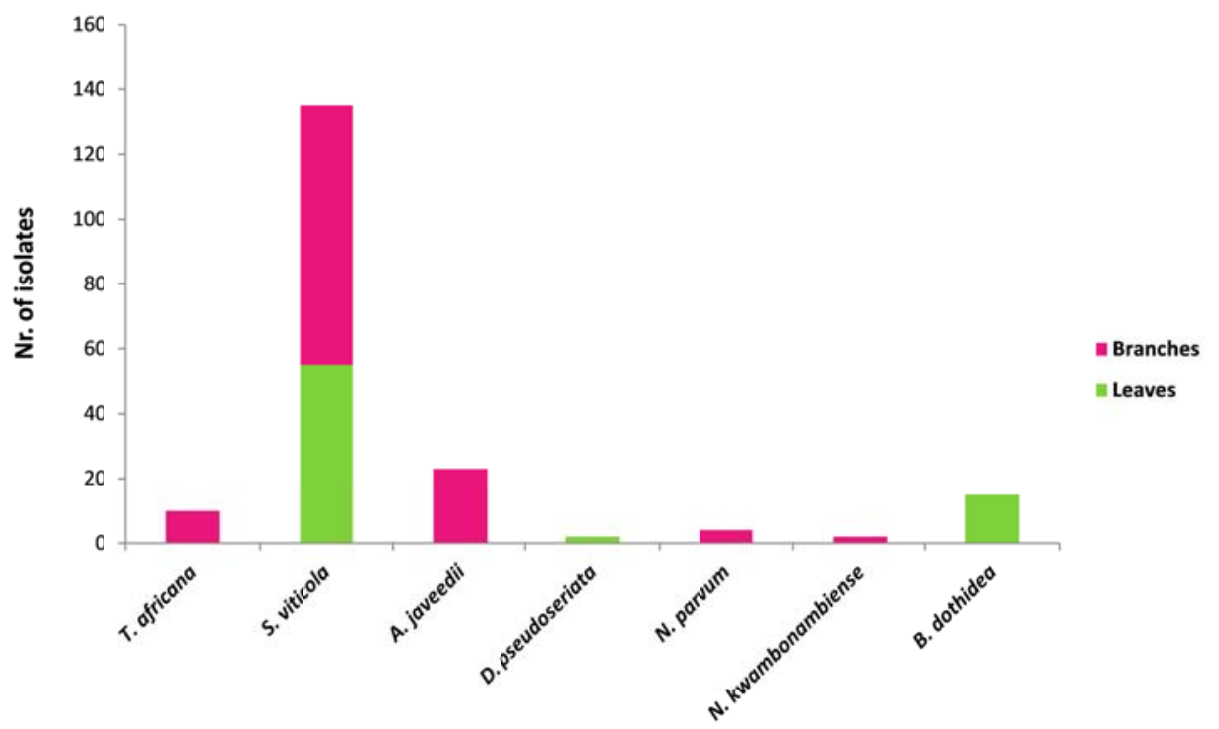

Fig. 5. Diversity of Botryosphaeriaceae species on leaves and branches of Acacia karroo, Celtis africana, Searsia lancea and Gymnosporia buxifolia 


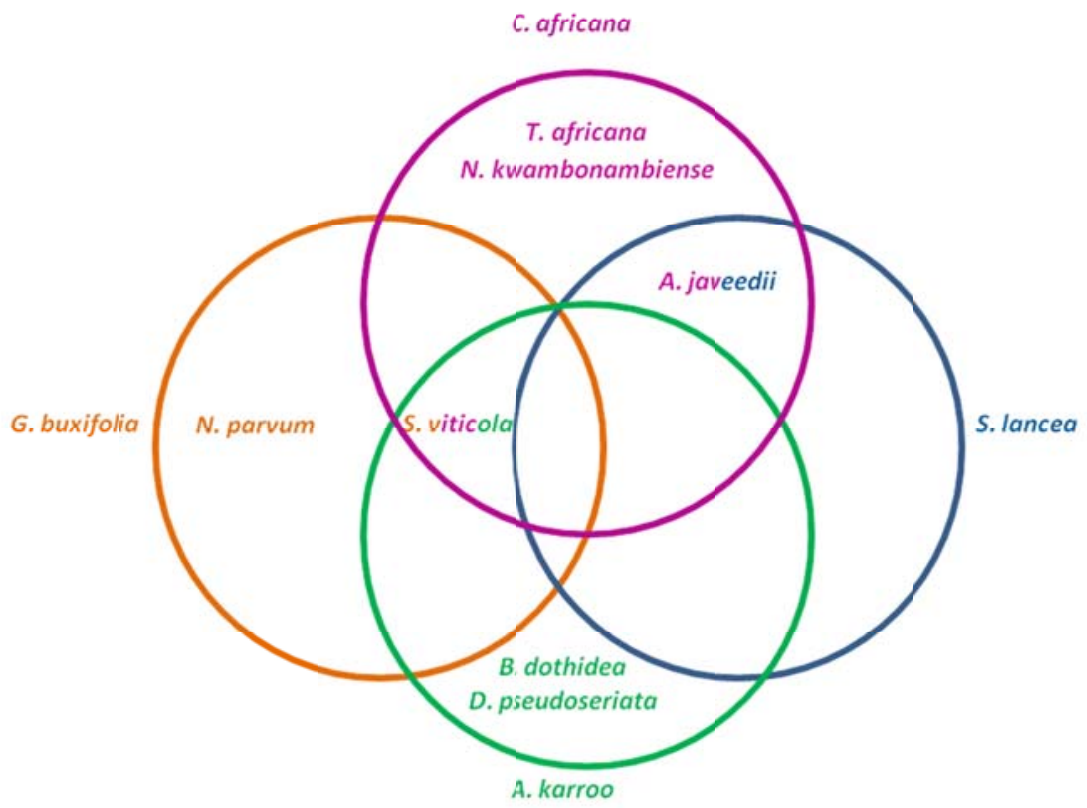

Fig. 6. The pattern of overlapping Botryosphaeriaceae species among Acacia karroo, Celtis africana, Searsia lancea and Gymnosporia buxifolia 
Table 1. Representative isolates of this study used in the phylogenetic analyses.

\begin{tabular}{|c|c|c|c|c|c|c|c|c|c|}
\hline \multirow[t]{2}{*}{ Isolate No. } & \multirow[t]{2}{*}{ Identity } & \multirow[t]{2}{*}{ Host } & \multirow[t]{2}{*}{ Tissue } & \multirow[t]{2}{*}{ Location } & \multirow[t]{2}{*}{ Collector } & \multicolumn{4}{|c|}{ GenBank } \\
\hline & & & & & & ITS & EF1- $\alpha$ & $\beta$-tubulin & LSU \\
\hline CMW38165 & Aplosporella javeedii** & Celtis africana & Branches & Pretoria, South Africa & $\begin{array}{l}\text { F. Jami \& M. } \\
\text { Gryzenhout }\end{array}$ & KC769938 & KC769846 & KC769903 & KC769979 \\
\hline \multicolumn{10}{|l|}{ CBS 133954} \\
\hline CMW38166 & A. javeedii* & Celtis africana & Branches & Pretoria, South Africa & $\begin{array}{l}\text { F. Jami \& M. } \\
\text { Gryzenhout }\end{array}$ & KC769939 & KC769847 & KC769904 & KC769980 \\
\hline CMW38167 & A. javeedii* & Celtis africana & Branches & Pretoria, South Africa & $\begin{array}{l}\text { F. Jami \& M. } \\
\text { Gryzenhout }\end{array}$ & KC769940 & KC769848 & KC769905 & KC769981 \\
\hline \multicolumn{10}{|l|}{ CBS 135852} \\
\hline CMW38168 & A. javeedii* & Searsia lancea & Branches & Pretoria, South Africa & $\begin{array}{l}\text { F. Jami \& M. } \\
\text { Gryzenhout }\end{array}$ & KC769941 & KC769849 & КC769906 & KC769982 \\
\hline \multicolumn{10}{|l|}{ CBS 135853} \\
\hline CMW38169 & A. javeedii* & Searsia lancea & Branches & Pretoria, South Africa & $\begin{array}{l}\text { F. Jami \& M. } \\
\text { Gryzenhout }\end{array}$ & KC769942 & KC769850 & KC769907 & KC769983 \\
\hline CMW38170 & A. javeedii* & Searsia lancea & Branches & Pretoria, South Africa & $\begin{array}{l}\text { F. Jami \& M. } \\
\text { Gryzenhout }\end{array}$ & KC769943 & KC769851 & KC769908 & KC769984 \\
\hline CMW38114 & $\begin{array}{l}\text { Botryosphaeria } \\
\text { dothidea }\end{array}$ & Acacia karroo & Leaves & Pretoria, South Africa & $\begin{array}{l}\text { F. Jami \& M. } \\
\text { Gryzenhout }\end{array}$ & KC769944 & KC769856 & KC769898 & - \\
\hline CMW38115 & B. dothidea & Acacia karroo & Leaves & Pretoria, South Africa & $\begin{array}{l}\text { F. Jami \& M. } \\
\text { Gryzenhout }\end{array}$ & KC769945 & KC769857 & KC769899 & - \\
\hline CMW38116 & B. dothidea & Acacia karroo & Leaves & Pretoria, South Africa & $\begin{array}{l}\text { F. Jami \& M. } \\
\text { Gryzenhout }\end{array}$ & KC769946 & KC769858 & KC769900 & - \\
\hline CMW38137 & Diplodia pseudoseriata & Acacia karroo & Leaves & Pretoria, South Africa & $\begin{array}{l}\text { F. Jami \& M. } \\
\text { Gryzenhout }\end{array}$ & KC769954 & KC769863 & KC769896 & - \\
\hline CMW38138 & D. pseudoseriata & Acacia karroo & Leaves & Pretoria, South Africa & $\begin{array}{l}\text { F. Jami \& M. } \\
\text { Gryzenhout }\end{array}$ & KC769955 & KC769864 & KC769897 & - \\
\hline CMW38131 & $\begin{array}{l}\text { Neofusicoccum } \\
\text { kwambonambiense }\end{array}$ & Acacia karroo & Branches & Pretoria, South Africa & $\begin{array}{l}\text { F. Jami \& M. } \\
\text { Gryzenhout }\end{array}$ & KC769949 & KC769862 & KC769902 & KC769988 \\
\hline
\end{tabular}




\begin{tabular}{|c|c|c|c|c|c|c|c|c|c|}
\hline CMW38426 & N. kwambonambiense & Celtis africana & Branches & Pretoria, South Africa & $\begin{array}{l}\text { F. Jami \& M. } \\
\text { Gryzenhout }\end{array}$ & KC769948 & KC769861 & KF512019 & KC769989 \\
\hline CMW 38161 & N. parvum & Gymnosporia buxifolia & Branches & Pretoria, South Africa & $\begin{array}{l}\text { F. Jami \& M. } \\
\text { Gryzenhout }\end{array}$ & KC769947 & KC769859 & KC769901 & - \\
\hline CMW 38079 & $\begin{array}{l}\text { Spencermartinsia } \\
\text { viticola }\end{array}$ & Acacia karroo & Branches & Pretoria, South Africa & $\begin{array}{l}\text { F. Jami \& M. } \\
\text { Gryzenhout }\end{array}$ & KC769952 & KC769866 & KC769895 & KC769987 \\
\hline CMW 38081 & S. viticola & Gymnosporia buxifolia & Branches & Pretoria, South Africa & $\begin{array}{l}\text { F. Jami \& M. } \\
\text { Gryzenhout }\end{array}$ & KC769951 & KC769865 & KC769894 & KC769986 \\
\hline CMW 38082 & S. viticola & Celtis africana & Branches & Pretoria, South Africa & $\begin{array}{l}\text { F. Jami \& M. } \\
\text { Gryzenhout }\end{array}$ & KC769950 & KC769867 & KC769893 & KC769985 \\
\hline CMW38423 & Tiarosporella africana* & Celtis africana & Branches & Pretoria, South Africa & $\begin{array}{l}\text { F. Jami \& M. } \\
\text { Gryzenhout }\end{array}$ & KC769956 & KC769852 & KC769909 & КC76999 \\
\hline \multicolumn{10}{|l|}{ CBS 133854} \\
\hline CMW38424 & T. africana* & Celtis africana & Branches & Pretoria, South Africa & $\begin{array}{l}\text { F. Jami \& M. } \\
\text { Gryzenhout }\end{array}$ & KC769957 & KC769853 & KC769910 & КC76999 \\
\hline \multicolumn{10}{|l|}{ CBS 135850} \\
\hline CMW38425 & T. africana* & Celtis africana & Branches & Pretoria, South Africa & $\begin{array}{l}\text { F. Jami \& M. } \\
\text { Gryzenhout }\end{array}$ & KC769958 & KC769854 & KC769911 & KC76999 \\
\hline \multicolumn{10}{|l|}{ CBS 135851} \\
\hline CMW38428 & T. africana* & Celtis africana & Branches & Pretoria, South Africa & $\begin{array}{l}\text { F. Jami \& M. } \\
\text { Gryzenhout }\end{array}$ & KC769959 & KC769855 & KC769912 & KC76999 \\
\hline
\end{tabular}

Culture collections: CMW- FABI, University of Pretoria, South Africa; CBS- Centraalbureau voor Schimmelcultures, Utrecht, The Netherlands. Isolate accession numbers in bold signify holotype cultures. Isolates for new described species are indicated with an asterisk $\left(^{*}\right)$ and ex-type isolates are indicated in bold type. 
Table 2. Polymorphic nucleotides from sequence data of the ITS, TEF-1 $\alpha$ and LSU showing the relationships between Aplosporella papillata and Aplosporella javeedii. Polymorphisms unique to $A$. javeedii are highlighted.

\begin{tabular}{|c|c|c|c|c|c|c|c|c|c|c|c|c|c|c|c|c|}
\hline \multirow[b]{2}{*}{ Identity } & \multirow[b]{2}{*}{ Isolate no. } & \multicolumn{15}{|c|}{ ITS } \\
\hline & & 111 & 162 & 166 & 169 & 168 & 169 & 176 & 177 & 181 & 441 & 447 & 473 & 482 & 495 & 553 \\
\hline Aplosporella papillata & CBS121780 & G & $\mathrm{T}$ & $\mathrm{C}$ & $\mathrm{C}$ & $\mathrm{C}$ & G & $\bar{G}$ & A & $\mathrm{G}$ & G & A & $\mathrm{G}$ & $\mathrm{C}$ & $\mathrm{G}$ & $\mathrm{C}$ \\
\hline A. papillata & CBS121782 & . & . & . & & . & . & . & . & & & & . & . & & . \\
\hline A. javeedii & CBS133954 & A & G & $\mathrm{T}$ & G & $\mathrm{T}$ & $\mathrm{T}$ & A & G & A & A & G & A & $\mathrm{T}$ & $\mathrm{C}$ & $\mathrm{T}$ \\
\hline A. javeedii & CMW38166 & . & . & . & . & . & . & . & . & $\cdot$ & r & . & . & . & . & . \\
\hline A. javeedii & CBS135852 & . & . & . & & . & . & . & . & & & . & . & . & v & . \\
\hline A. javeedii & CBS135853 & . & . & . & & . & . & . & . & & & . & . & . & & . \\
\hline A. javeedii & CMW38169 & . & . & . & & . & . & . & . & & & . & . & . & . & . \\
\hline A. javeedii & CMW38170 & . & . & . & & . & . & . & . & . & . & . & . & . & . & . \\
\hline
\end{tabular}

\begin{tabular}{|c|c|c|c|c|c|c|c|c|c|}
\hline \multirow[b]{2}{*}{ Identity } & \multirow[b]{2}{*}{ Isolate no. } & \multicolumn{6}{|c|}{ TEF-1 $\alpha$} & \multicolumn{2}{|c|}{ LSU } \\
\hline & & 89 & 142 & 143 & 148 & 171 & 303 & 352 & 373 \\
\hline Aplosporella papillata & CBS121780 & A & G & $\mathrm{C}$ & A & $\mathrm{C}$ & $\mathrm{C}$ & $\mathrm{C}$ & $\mathrm{T}$ \\
\hline A. papillata & CBS121782 & & & . & . & . & . & . & . \\
\hline A. javeedii & CBS133954 & G & $\mathrm{C}$ & G & $\mathrm{C}$ & G & G & $\mathrm{T}$ & $\mathrm{C}$ \\
\hline A. javeedii & CMW38166 & & & . & . & . & . & . & . \\
\hline A. javeedii & CBS135852 & & & . & . & . & . & . & . \\
\hline A. javeedii & CBS135853 & & . & . & . & . & . & . & . \\
\hline A. javeedii & CMW38169 & & & . & . & . & . & . & . \\
\hline A. javeedii & CMW38170 & & & . & . & . & . & . & . \\
\hline
\end{tabular}


Table 3. Polymorphic nucleotides from sequence data of the LSU showing the relationships between Tiarosporella madreeya and Tiarosporella africana. Polymorphisms unique to $T$. africana are highlighted.

\begin{tabular}{|c|c|c|c|c|c|c|c|c|c|c|c|c|}
\hline \multirow[b]{2}{*}{ Identity } & \multirow[b]{2}{*}{ Isolate no. } & \multicolumn{11}{|c|}{ LSU } \\
\hline & & 137 & 412 & 425 & 435 & 441 & 442 & 466 & 468 & 493 & 630 & 633 \\
\hline Tiarosporella madreeya & CBS532.76 & $\mathrm{T}$ & $\mathrm{C}$ & $\mathrm{C}$ & A & $\mathrm{T}$ & $\mathrm{C}$ & $\mathrm{T}$ & G & $\mathrm{T}$ & G & A \\
\hline T. africana & CBS133854 & $\mathrm{C}$ & $\mathrm{T}$ & $\mathrm{T}$ & G & $\mathrm{C}$ & $\mathrm{T}$ & $\mathrm{C}$ & $\mathrm{T}$ & A & $\mathrm{T}$ & $\mathrm{C}$ \\
\hline T. africana & CBS135850 & . & . & . & . & . & . & . & . & . & . & . \\
\hline T. africana & CBS135851 & & . & . & . & . & . & . & . & . & & . \\
\hline T. africana & CMW38428 & & . & . & . & . & . & . & . & . & . & . \\
\hline
\end{tabular}

